\title{
Plume origin of the Central Arctic uplifts evolution in the Amerasian Basin of the Arctic Ocean
}

\author{
V. V. Verba ${ }^{1}$ and A. I. Truhalev ${ }^{1}$ \\ Received 25 November 2015; accepted 16 January 2016; published 3 February 2016.
}

Geological and geophysical aspects of the Central Arctic Elevations in the Arctic Ocean have been analyzed in order to consider their correspondence to signs of a mantle plumes activity accepted by most scientists. The manifestation in topography (vast arched uplift), extensive Late Mesozoic intraplate basaltic magmatic activity (High Arctic Large Igneous Province, HALIP), and gravimetric and magnetometric characteristics have been outlined to indicate that the area of the Central Arctic Elevations is a block of the ancient continental crust. The block underwent intensive destructive transformations driven by mantle upwelling but with preservation of general geophysical properties of continental crust, and subsidence up to bathyal depths at the neotectonic level. KEYWORDS: Arctic; aeromagnetics; mantle plume; High Arctic large igneous province.

Citation: Verba, V. V. and A. I. Truhalev (2016), Plume origin of the Central Arctic uplifts evolution in the Amerasian Basin of the Arctic Ocean, Russ. J. Earth. Sci., 16, ES1002, doi:10.2205/2016ES000562.

\section{Introduction}

Requirements of scientific justification for extended continental shelf delineation in the Arctic Ocean challenged the Arctic states which in turn led to the wide range of conducted deep geological and geophysical studies. Foremost, these studies have been directed to the gain of geological knowledge about nature of the Central Arctic Elevations (Lomonosov Ridge, Alpha-Mendeleev Rise) those are transition zones.

According to a number of scientists, the most part of the Amerasian Basin represented the ancient Hyperborean platform in the pre-oceanic stage. But despite of some progress in the polar sciences, this ancient continent, its nature and very existence are still under discussion. Cretaceous intraplate basaltic magmatism occurs widely across the Arctic region as dikes, sills and flows. That was the reason to associate them into the High Arctic Large Igneous Province (HALIP) which constituents are the Franz Josef Land's volcanic plateau, Cretaceous dike belts and shallow igneous rocks of the Canadian Arctic Archipelago and Greenland. The center of radial dike belts is traced back on the Queen Elizabeth Islands. As stated in preliminary data, these dike belts was formed in the Cretaceous and Cainozoic. Also many studies established that the Alpha-Mendeleev volcanic

\footnotetext{
${ }^{1}$ Russian Research Institute of Geology and Mineral Resources of the World Ocean named after Igor Gramberg (VNIIOkeangeologia named after I. S. Gramberg), St. Petersburg, Russia

Copyright 2016 by the Geophysical Center RAS.

http://elpub.wdcb.ru/journals/rjes/doi/2016ES000562-res.html
}

plateau formed in the end of Cretaceous together with intraplate basic rocks on the Eurasian continental shelf (De Long Plateau), Canadian Arctic Archipelago and in the Cape-Washington area (North of Greenland).

\section{Geological and Geophysical Characteristics of Mantle Plumes and Evidences of Their Occurrence in the Arctic Ocean}

Morgan 1993 and Grachev 2000 published the classification of geological and geophysical signs of mantle plumes occurrence.

In that light, authors analyzed all modern geological and geophysical data on the Northern Polar Regions, especially concentrated at the Amerasian Basin. Based on bathymetrical data, the Lomonosov Ridge, Alpha Ridge, Mendeleev Rise, Chukchi Cap and Northwind Ridge were determined to form a single orographic area within the Amerasian Basin. Basins in this system are its components, which can be referred to subsidence basins formed as a result of crustal destruction [Gramberg and Naryshkin, 2000 Naryshkin, 1995].

Grachev 2001 concluded that the geomorphological manifestation is the most illustrative and simplest feature of mantle plume activity. Mantle plumes are expressed in topography as a vast arched uplift. Geomorphology of the Central Arctic Elevations is in total agreement with the sign mentioned above.

Magnetic anomalies of the Uplifts comply with the regional intense magnetic anomaly combining homogeneous magnetic anomalies of interference, mosaic type. Magnetic 
anomalies of the Amerasian province abruptly cut off by a fault zone in the area of Greenland and Arctic Canadian Archipelago along the continental slope, but then, on the coast of the North American continent observed magnetic anomalies are similar to the anomalies of the Alpha and Lomonosov ridges [Døssing, 2013 Funck et al., 2011].

According to the nature of local magnetic anomalies, the regional magnetic anomaly is caused by the effect of superposition of the local anomalies from magnetic sources widespread in the crust [Verba et al., 2002. The similar regional anomaly is established over the province of flood basalts of the Tunguska syneclise [Verba and Fedorov, 2003. 2006 .

A strong correlation is observed between the magnetic anomalies and bathymetry of the Alpha Ridge and Mendeleev Rise [Leonov, 2000, Weber, 1986]. The behavior of the local magnetic anomalies of the Mendeleev Rise differs with a significant decrease in the intensity of the field. The degree of differentiation and anisotropy of magnetic anomalies of Mendeleev Rise is noted to be significantly lower than that of the Alpha Ridge. Authors explained this feature due to deep of igneous rocks occurrence on the Mendeleev Rise, and probably less magnetic saturation of the section with magnetic masses. The depth range of magnetic bodies occurrence is wide. It ranges from $2-8 \mathrm{~km}$ in isolated areas up to $10 \mathrm{~km}$, which indicates a throughout vertical saturation of the crustal section with magnetic formations to the entire depth of the geological section. However, the dependence of local magnetic anomalies intensity from topography clearly shows that most of the sources are spatially inclined to the surface of the acoustic basement [Leonov, 2000 Weber, 1986 .

According to Bruvoll et al. 2012, acoustic facies are widely distributed on the Mendeleev Rise at the base of the sedimentary cover, interpolated as Cretaceous (before Campanian) basaltic flows and sills. The surface of the acoustic basement has the most contrast boundary of velocity section in the sedimentary cover within the Alpha Ridge, Lomonosov Ridge and Mendeleev Rise. This boundary is assumed to be the base of the upper Cretaceous sediments [Jokat et al., 2013], likely saturated with magmatic formations.

Continental margins of these regions are characterized by continental rifting in the Permian-Triassic and Cretaceous [Barents shelf plate, 1988 Grantz, 2011]. Therefore, their common geological nature can be assumed. The magnetic field of the Lomonosov Ridge is not reflected as a cohesive structure of the interference type, which is almost indistinguishable from the magnetic anomalies of the Marvin Spur and Alpha Ridge [Døssing et al., 2013].

The Eastern Siberian flank of the Lomonosov Ridge is distinct from the Greenland one by a significant decrease in the intensity of local anomalies of up to 100 to $200 \mathrm{nT}$ and the increase of the period of anomalies. This could be caused by more deep-source anomalies, or a less igneous activity.

New substantive data on this subject were obtained during the interpretation of materials of high-precision aeromagnetic survey of LOMGRAV-2009 [Døssing et al., 2013]. The Southern Greenland part of the Lomonosov and Alpha ridges was allocated to local magnetic anomalies of the North-West strike. According to the authors, they can be characterized by a series of igneous rock dikes connected directly to the giant swarm of dikes in the coastal area of Greenland and Cretaceous dike complex of Franz Josef Land (Figure 1). The field distribution of the latter was distinctly mapped according to the materials of Russian aeromagnetics and the data of parametric drilling in Alexander Island [Dibner, 1998].

The crustal thickness is up to $40 \mathrm{~km}$ in some cases depending on the crustal extension and reduction rate. Signs of a thinned (reduced) crust were commonly observed on the flank of Alpha Ridge $(23 \mathrm{~km})$, Lomonosov Ridge (22$24 \mathrm{~km})$, Podvodnikov Basin $(20-25 \mathrm{~km})$, and Mendeleev Rise (30-34 km) [Kaminsky, 2014].

Stretched continental crust was formed, in our opinion, as a result of the widespread continental rifting in the JurassicCretaceous time and the processes of intraplate igneous activity, which was confirmed by direct geological observations.

\section{Mantle Plume Activity}

The large volume of volcanic rocks of the intraplate type is often considered as an indicator of the lower mantle superplume activity [Grachev, 2001]. In this regard, particular interest has been focused on the manifestations of intraplate magmatism of the Central Arctic Elevations in Amerasian Basin. A mantle plume impact is accompanied by upwelling pulses, where the initial impact on the continental lithosphere is reflected in its extension and destruction by type of an active rifting.

The Mesozoic-Cenozoic basalts in the Arctic Ocean inland were particularly well studied in the North-Western part. The studies included the Eastern part of Svalbard, King Charles Land, Franz Josef Land and De Longa islands, as well as the Northern part of Ellesmere and Axel Heiberg islands of the Canadian Arctic Archipelago. The basaltic magmatism was of the Late Jurassic to Late Cretaceous age, and sometimes up to Paleogene [Grachev et al., 2001, Silantyev et al., 2004.

According to Stolbov 2011, the complex of flood basalts of Franz Josef Land is presented by covers, flows, sills, dikes, and vent facies of volcanic assemblage (volcanic necks). Driven up to $3500 \mathrm{~m}$ and penetrated the Vendian formation, the Nagurskaya well log had volume of $30 \%$ of the Cretaceous dolerites, where the saturation with dolerites increased to the section bottom [Dibner, 1998. The whole of developed Franz Josef Land's rock types is characterized by the distribution of REE which is typical for continental plateau basalts. Age of the volcanic rocks of the Franc Josef Land is in interval of 95-161 My [Karjakin et al., 2009].

Thickness of similar sills in the Central and Eastern parts of Svalbard reaches up to $100 \mathrm{~m}$ with the extent up to several kilometers. In the Eastern Svalbard, extrusive and subvolcanic facies are complemented by subhorizontal flows of plateau basalts.

On the Barents Sea shelf, Jurassic-Cretaceous igneous rocks are mainly confined to a graben system. Basaltic sills and gabbro-diabases on the saddle between the North and South Barents basins. Basalts of the Eastern shelf of Sval- 

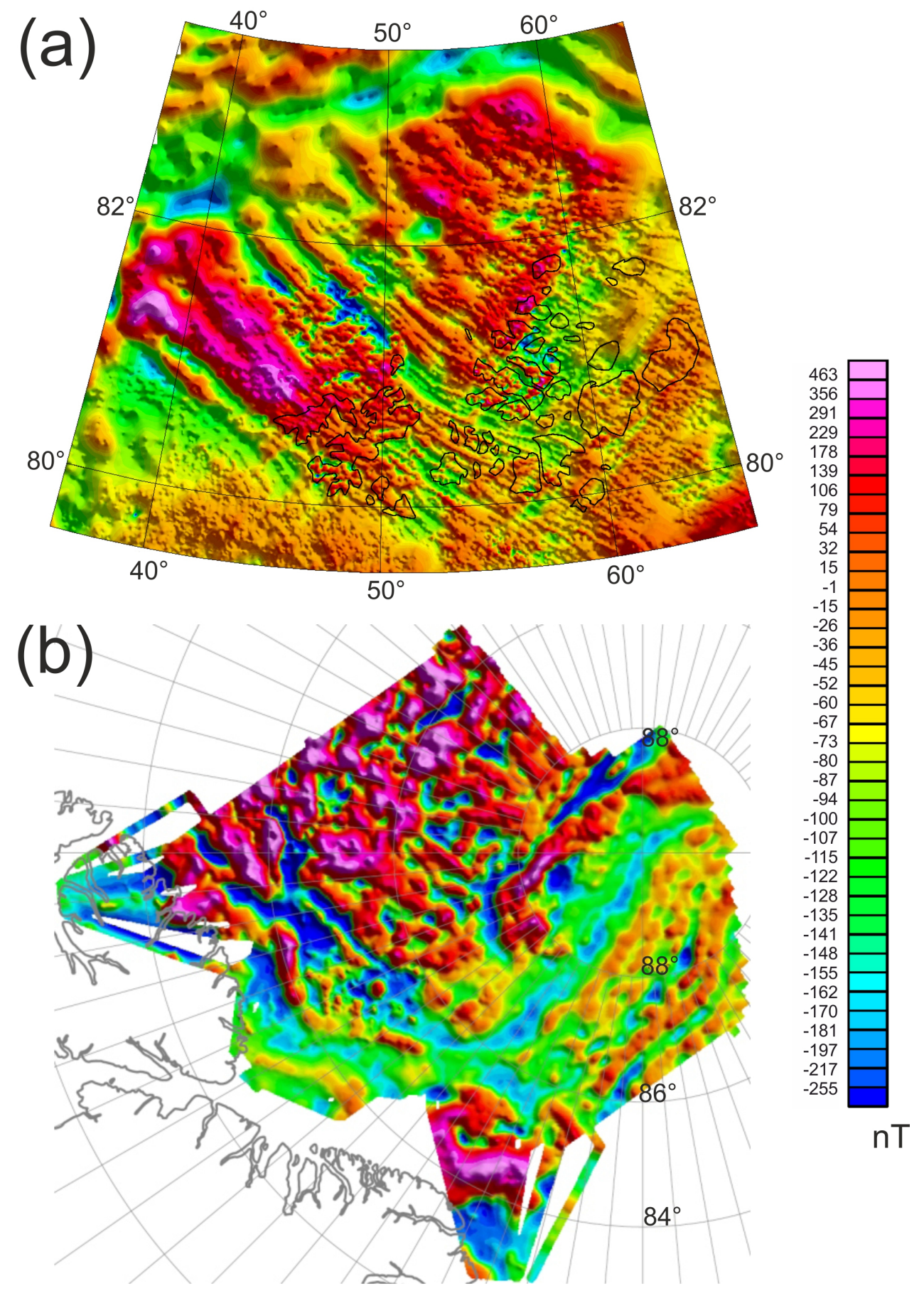

Figure 1. Magnetic anomalies: (a) Franz Josef Land, Aeromagnetics of 1 : 500000 scale, (PMGRE, 1991-1995); (b) South of the Lomonosov and Alpha ridges, LOMGRAV-2009 [Matzka et al., 2010].

bard and St. Anna Graben were dated as the Late JurassicAlbian (145 My and 110-105 My). Basaltoids from the Nagurski well were dated (K-Ar) with $151 \pm 11$ (Kimmeridgian) and $103 \pm 7$ (Albian) My.

Jurassic-Cretaceous subvolcanic rocks were mapped in the Novaya Zemlya archipelago and Franz Josef Land. A dike complex of the Cretaceous age was identified on the coast of Greenland in the area of Ellesmere Island.

All these rocks belong to Fe-Ti basalts enriched of LREE and similar to the flood basalts of the Deccan Plateau and Siberia [Almukhamedov et al., 1999 .

In the Eastern Arctic, Jurassic-Lower Cretaceous igneous 
rocks were mapped on the Islands of the East Siberian, Chukchi, and Beaufort seas, as well as in Sverdrup Basin, i.e. across the Eurasian and North American continental framing of the Canadian Basin. This interval is part of a bimodal volcanic association in the New-Siberian Islands with conjunction of tuffaceous formations.

Igneous rocks of the Central part of the De Long Plateau present alkaline basalts from two age groups: Middle Cretaceous (Bennett Island) and Late Pleistocene (Zhokhov and Vilkitsky islands). Intraplate igneous activity was manifested in the framing of the Canada Basin. The Kimmeridgian basalts $(152 \pm 6 \mathrm{My})$ were determined in the Sverdrup Basin. Moreover, basalts of 110-100 My age and 95 $\pm 0.2 \mathrm{My}$ were also revealed.

There is still an open question how this igneous activity was manifested in the Central part of the Amerasian Basin.

In the summer of 2012, the Ministry of Natural Resources of the Russian Federation (MNR RF) was carried out the expedition to the area of the Mendeleev Rise and Podvodnikov Basin [Morozov et al., 2013]. The Arctic-2012 expedition of MNR RF conducted the geological sampling of the Mendeleev Rise seabed. Only up to $20 \%$ of studied rocks were igneous (granitoids, gabbro-dolerites, rarely basalts). In the southern part of the Rise, volcanic rocks of the trachyandesite-trachybasalt were found with an age of $260 \mathrm{My}$, typical of the Siberian flood basalts and bimodal complexes of Western Siberia. In the Northern part of the Mendeleev Rise and Alpha Ridge, flat lavas of trachybasalts are aged of $127 \mathrm{My}$, which are typical for other regions of the Arctic. The chemistry of the basalts tends to continental rift formations and they have a great resemblance with the famous plateau-basalts of the Deccan Plateau [Morozov et al., 2013.

Based on the complex research of the total volume of rock bottom material of the Arctic-2012 expedition, the continental basement of the Mendeleev Rise was created by the Cretaceous and Permo-Triassic basaltic (trap, rift-related) igneous activity. The latter was compared with the flood basalts of the Siberian Platform or rift-related basalts of the West Siberian Plate. According to the authors [Morozov et al., 2013, Mendeleev Rise can be considered as a deep subsided part of the Eurasian continental margin, retaining a close relationship with the structures of the surrounding islands and mainland. This conclusion is confirmed by the results of laboratory research of magmatic rocks samples from the high-latitude expeditions Arctic-2000, Arctic-2005 and Polarstern-2008, taken in the Mendeleev Rise. Here were raised gneiss-granites of early Precambrian age of 2.7-1.9 billion years old, and were found the fragments of Neoproterozoic dolerites and gabbro-dolerites. They differ distinctly from the Cretaceous mafic rocks and by age correspond to the Neoproterozoic [Morozov et al., 2013].

Along with old dredged igneous rocks, basaltic cores were obtained with the use of the subwater drilling in the Northern and Southern parts of the Mendeleev Rise which are occurring at the boundary of the Late Mesozoic sedimentary cover and acoustic basement.

Presented volcanics are high-Ti trachybasalts with high value of alumina and variable ratio of potassium and sodium. In the southern part of the Mendeleev Rise, trachytes and trachyandesites form a rift-related bimodal association. These rocks show Late Permian age of $260 \mathrm{My}$, typical of the Siberian traps and bimodal complexes of the Western Siberia. The trachybasalts from the Northern part of the Rise are of $127 \mathrm{My}$ age typical of HALIP.

\section{Conclusions}

All the combined and analyzed materials have confirmed, in our view, the previous developed conception, according to those, the most part of the Arctic Basin is a continental geoblock related regionally to the Central Arctic Elevations of the Arctic Ocean. The Central Arctic Elevations and the Northern part of the Russian Eastern Arctic shelf represent a single complex of geological structures with the common evolution history and with syn-oceanic structural and compositional transformations of the continental crust. This complex was divided to shelf and bathyal parts as a result of neotectonic subsidence of the Arctic Basin [Truhalev and Poselov, 2008. The area of the Central Arctic Elevations has preserved as a transarctic bridge of the continental crust between Eurasian and North American continents.

According to Gaina 2011, Døssing 2013, Bruvoll 2012 and Jokat 2013, the part of the Amerasian Basin (i.e. the Province) was formed during the Late Mesozoic-Cenozoic magmatic activity.

This block underwent the influence of a mantle plume in Cretaceous [Khain and Filatova, 2007, Kovalenko et al., 2009 Cretaceous plume magmatic activity expressed in the most part of the Arctic Ocean continental margins. The single mantle plume which evolution led to the formation of the Arctic Ocean was likely breaking up to smaller ones. These new plumes occurred in the distinct regions of intraplate magmatic activity (regions of Franz Josef Land, De Long Plateau, Alpha Ridge, Greenland-North Canada) that formed in total the High Arctic Large Igneous Province (HALIP). In the light of all analyzed geological and geophysical data, HALIP was outlined on Figure 2

\section{References}

Almukhamedov, A. I., A. Y. Medvedev, N. P. Kirda (1999), Comparative analysis of geodynamic settings of the PermoTriassic magmatism in East and West Siberia, Geol. Geophys. J., $11, \quad 1575-1587$.

Barents Shelf Plate (1988), Tr. PGO "Sevmorgeologia", $v$. 19, 263 pp., Nedra, Leningrad.

Bruvoll, V., Y. Kristoffersen, B. Coakley, J. Hopper, S. Planke, A. Kandilarov (2012), The nature of the acoustic basement on Mendeleev and northwestern Alpha ridges, Arctic Ocean, Tectonophysics, 514-517, 123-145.

Dibner, V. D., Ed. (1998), Geology of Franz Josef Land, Norsk Polarinstitutt, Oslo.

Døssing, A., J. R. Hopper, A. V. Olesen, et al. (2013), New aero-gravity results from the Arctic: Linking the latest Cretaceous-early Cenozoic plate kinematics of the North Atlantic and Arctic Ocean, Geochem. Geophys. Geosys., 14, No. 10, 4044-4065, doi:10.1002/ggge.20253 


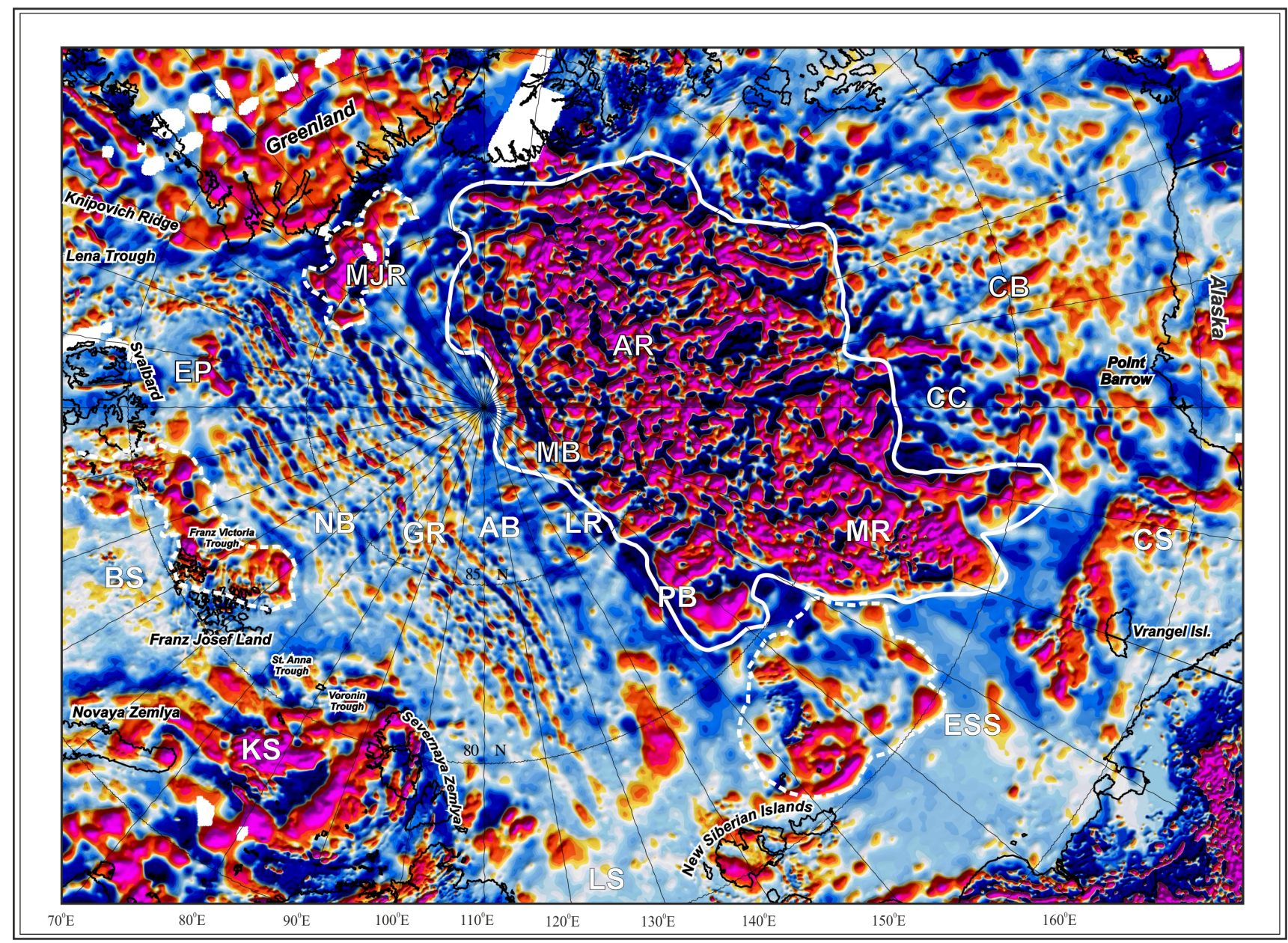

$\begin{array}{lllllll}178 & -133 & -106 & -87 & -72 & -60 & -49\end{array}$

Figure 2. Magnetic anomalies in the Arctic Ocean [Kaminsky, 2014]. High Arctic Large Igneous Province (HALIP): Bold line - Province outlined according to Aeromagnetics; Dashed line - Regions of mantle plumes formations outlined according to the geological and geophysical data.

Funck, T., H. R. Jackson, J. Shimeld (2011), The crustal structure of the Alpha Ridge at transition of the Canadian polar margin: Results from a seismic refraction experiment, $J$. Geophis. Res., 116, B.12101. doi:10.1029/2011JB008411

Gaina, C., et al. Circum-Arctic mapping project: New magnetic and gravity anomaly maps of the Arctic, Arctic Petroleum Geology (Eds. A. M. Spencer, D. Gautier, A. Stoupakova, A. Embry, and K. Sørensen), p. 39-48, Geol. Soc., London.

Grachev, A. F. (2000), Mantle plumes and problems of geodynamics, Izvestiya, Phys. Solid Earth, 36, 263-294.

Grachev, A. F. (2001), New view on the origin of magmatism of the Franz Josef Land, Izvestiya, Phys. Solid Earth, 37, $744-756$.

Grachev, A. F., et al. (2001), New K-Ar ages for basalts from Franz Josef Land, Russ. J. Earth Sci., 3, No. 1, 79-82, doi:10.2205/2001ES000053

Gramberg, I. S., G. D. Naryshkin (2000), The peculiarities of the bottom topography in the Arctic deep-sea basin of the Arctic Ocean, Geology and geomorphology of the Arctic ocean in connection with the problem of the outer limit of the continental shelf of the Russian Federation in the Arctic Basin, p. 53-72, VNIIOkeangeologia, Saint Petersburg.

Grantz, A., P. Hart, V. Childers (2011), Geology and tec- tonic development of the Amerasia and Canada Basins, Arctic Ocean, Arctic Petroleum Geology, \# 35, p. 771-799, Geological Society, London. doi:10.1144/M35.50

Jokat, W., M. Ickrath, J. O'Connor (2013), Seismic transect across the Lomonosov and Mendeleev ridges: Constraints on the geological evolution of the Amerasia Basin, Arctic Ocean, Geophys. Res. Lett., 40, No. 19, 5047-5051. doi:10.1002/grl.50975

Kaminsky, V. D., V. A. Poselov, G. P. Avetisov, Eds. (2014), Russian Arctic Geotransects, 164 pp., VNIIOkeangeologia, Saint Petersburg.

Karjakin, Ju. V., et al. (2009), Mezozojskie magmaticheskie kompleksy arhipelaga Zemlja Franca-Iosifa, Geologija poljarnyh oblastej Zemli, p. 257-263, GEOS, Moscow.

Khain, V. E., N. I. Filatova (2007), Main stages of tectonic evolution of the Eastern Arctic, DAN, 415, No. 4, 518-523.

Kovalenko, V. I., V. V. Yarmolyuk, O. A. Bogatikov (2009), Modern supercontinent in the Northern hemisphere of the Earth (North Pangea): magmatic and geodynamic evolution, DAN, 427, No. 3, 354-358.

Leonov, V. O. (2000), Crustlal types of Alpha and Mendeleev ridges in the light of correlation analysis of magnetic and bathymetric data, Publication "Geological and geophysical charac- 
teristics of the lithosphere in the Arctic region", 3, p. 33-38, VNIIOkeangeologia, Saint Petersburg.

Matzka, J., T. M. Rasmussen, A. V. Olesen, J. E. Nielsen, R. Forsberg, N. Olsen, J. Halpenny, J. Verhoef (2010), A new aeromagnetic survey of the North Pole and the Arctic Ocean north of Greenland and Ellesmere Island, Earth, Planets and Space, 62, No. 10, 829-832.

Morgan, J. Ph., P. M. Shearer (1993), Seismic constraints on mantle flow and topography of the $660 \mathrm{~km}$ discontinuity: evidence for the whole-mantle convection, Nature, 365, 506511.

Morozov, A. F., O. V. Petrov, S. P. Shokalsky, et al. (2013), New geological data confirming the continental nature of the Central Arctic uplifts area, Regional Geology and Metallogeny, No. 53, 34-55. (in Russian)

Naryshkin, G. D. (1995), Orographic map of the Arctic Basin. Scale 1:5 000 000, Karttakyerus, Helsinki.

Silantyev, S. A., et al. (2004), Intraplate magmatism of the De Long Islands: A response to the propagation of the ultraslow-spreading Gakkel Ridge into the passive continental margin in the Laptev Sea, Russ. J. Earth Sci., 6, No. 3, 153-183, doi:10.2205/2004ES000150

Stolbov, N. M. (2011), The evolution model of the plume of Franz Joseph Land. Collection of "Modern state of Earth Sciences", Proceedings of the International Conference, devoted to memory of $V$. E. Khain, p. 1792-1795, MSU, Moscow.

Truhalev, A. I., V. A. Poselov (2008), Historical, genetic and geodynamic links of the elevations in the Amerasian Basin with the structures of the East Arctic shelf, 60 Years in the Arctic, Antarctic and World Ocean. Collection of Scientific Works, p. 263-274, VNIIOkeangeologia, Saint Petersburg.

Verba, V. V., V. I. Fedorov (2006), The nature of the magnetic anomalies of the Central Arctic Elevations Province in the Amerasian Basin of the Arctic Ocean, Geofizicheskij Zhurnal, 28, No. 5, 95-103.

Verba, V. V., V. I. Fedorov (2003), Geological Origin of the Magnetic Anomaly Field in the Central Amerasian Basin (Arctic Ocean), Proceedings of the Fourth International conference on Arctic margins (ICAM IV), R. A. Scott and D. K. Thurston (Eds.), OCS study MMS 2006-003, p. 173-178, U.S. Department of the Interior, Anchorage, Alaska.

Verba, V. V., et al. (2002), The nature of geophysical fields in the Arctic, Russian Arctic: Geological History, Mineralogy and Geoecology, D. A. Dodin and V. S. Surkov (Eds.), p. 142149, VNIIOkeangeologia, Saint Petersburg.

Weber, J. R. (1986), The Alpha Ridge: Gravity, Seismic and Magnetic Evidence for a Homogenous, Mafic Crust, J. Geodynamics, 6, No. 1-4, 117-136.

A. I. Truhalev and V. V. Verba, Russian Research Institute of Geology and Mineral Resources of the World Ocean named after Igor Gramberg (VNIIOkeangeologia named after I. S. Gramberg), Saint Petersburg (verba@sevmorgeo.com) 